\title{
An Analysis of Various Types of Supply Chain Management Systems: Case of Global Public Sector versus Private Sector Procurement
}

\section{Sakhile Manyathi ${ }^{1}$}

'Deputy Director: Supply Chain Management Training Department of National Treasury, South Africa.

\begin{abstract}
Public institutions are subject to huge range of legislative restrictions, controlled by the legislative, executive and judicial authorities and subject to criticism by the public at large as compared to private sector procurement processes which are led by profit motives (Fourie, 2009). In both public and private sector procurement, the goods, services and or works have to be acquired, which is the most similarity between these two sectors. In the final analysis, Oughton (2007) alluded to the fact that, it is how well these concepts work that truly determine their worth; it is clear that public and private sector supply chains truly are "two sides of the same coin" and that many private sector best practices can be used in the public sector with great success and with little or no modification; thereby fostering the much needed partnership between these two sectors. A general concern among public sector procurement processes is a low level of trust to the suppliers in that the best price offer ultimately is selected or given high weight like in the South African 80/20 and 90/10 preferential point system, however there is a contrast, in that the private sector often considers performance equally or even more important than price so the 80/20 and 90/10 principle wouldn't work in private sector procurement. Private sector procurement managers are said to be more interested in the quality of performance than costs; therefore the public sector procurement officials can learn more of these good practices from the private sector.
\end{abstract}

Keywords: Public sector procurement, Private sector procurement, Differences, Partnerships, Political ambiance.

\section{Contents}

1. Introduction

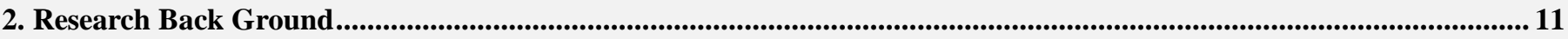

3. Research Literature Review ..................................................................................................................................................... 11

4. Public Sector Procurement Compared to Private Sector Globally .............................................................................................12

5. Factors Affecting Supply Chains in the Public Procurement ....................................................................................................... 13

6. Partnership between Private and Public Sector in Procurement ........................................................................14

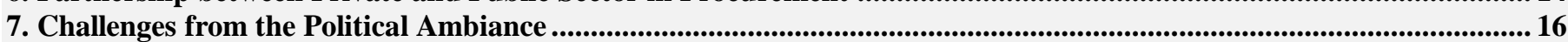

8. Lessons to be learned by Public Sector from Private Sector Procurement Practices ............................................................. 16

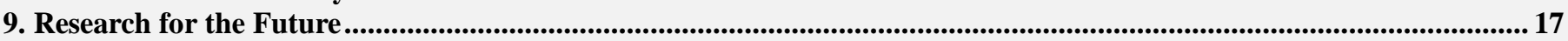

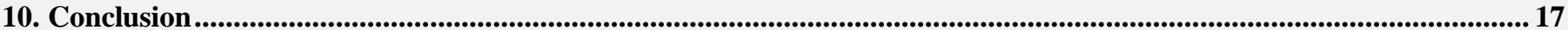

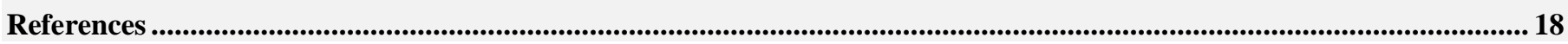

Citation | Sakhile Manyathi (2017). An Analysis of Various Types of Supply Chain Management Systems: Case of Global Public Sector versus Private Sector Procurement. Asian Journal of Social Sciences and Management Studies, 4(1): 10-19.

DOI:

$\operatorname{ISSN}(\mathbf{E})$ :

ISSN(E) :
ISSN(P) :

Licensed:

$2518-0096$

Contribution/Acknowledgement: All authors contributed to the conception and design of the study.

Competing Interests:

Transparency:

The author declares that there are no conflicts of interests regarding the publication of this paper.

The author declares that there are no conflicts of interests regarding the publication of this paper.
The authorm that the manuscript is an honest, accurate, and transparent account of the st

History:

Ethical:

Publisher: vital features of the study have been omitted; and that any discrepancies from the study as planned have been explained
Received: 20 October 2015/ Revised: 19 October 2016/ Accepted: 26 October 2016/ Published: 1 November 2016
This study follows all ethical practices during writing. follows all ethical practices during writing.

Asian Online Journal Publishing Group 


\section{Introduction}

The main focus on public procurement has never been at a higher level in most research studies conducted globally. The procurement performed in public sector is still following behind the procurement performed in private sector in scientific analysis and accumulated knowledge. Papers about public procurement are usually either in documentary form (explaining the situation in a certain specific country).

This article is intended as a contribution towards filling some of the gaps identified above. In this article the scene is set for the following sections and sub-sections by analyzing public procurement as an area of expertise. This is done by first considering the differences between public sector procurement and private sector procurement. It will become clearer that demands or requirements put on public procurement from various sources determine the characteristics of public procurement. As these demands are additional demands to those on private sector procurement, they define the complexity of the public procurement. Another viewpoint on this complexity and on the nature of public procurement is provided by the various interests that have to be administered in public procurement e.g. political interests, socio-economic goals etc.

In both public and private sector procurement, the goods, services and or works have to be acquired, and in both sectors there are good reasons to strive for the best deal in obtaining the required goods, services and or works.

Even though there are similarities that exist in both public and private sector procurement; it is scientifically proven that the public sector procurement is different from the private sector procurement (Erridge, 1996; Thai, 2001; Thai et al., 2004). This is further confirmed by the exerted demands found in the public sector as compared to the private sector procurement (Neill and Batchelor, 1999).

\section{Research Back Ground}

The most dominant character of developing countries is its public procurement accounting for roughly $9-13 \%$ of the Gross Domestic Product (GDP); therefore this indicates that public procurement requires special attention for faster growth of the developing economies as non-compliance is sky rocking high (Odhiambo and Kamau, 2003). Officials working in public sector procurement are facing difficult conditions in that the environment is highly regulated with various statues, policies, regulations and directives sometimes which are confusing. They operate in an environment of increasingly intense scrutiny and accelerated changes driven by technology, program reviews, and public and political expectations for service delivery and improvements. These combined; normally result into growing institutional complexity and risks. However Ntayi et al. (2009) observes that millions of rands get wasted due to inefficient and ineffective procurement structures, policies and procedures as well as failure to impose sanctions for violation of procurement rules thus resulting in poor service delivery; hence the public procurement is the acquisition of goods, services and works by the procuring authority using public funds (World Bank, 2005). Many internal and external stakeholders of any government are affected by whether the government complies with its set procurement regulations and policies; which in turn determines whether the government met its objectives or not i.e. service delivery.

Attempting to improve the management of public procurement, many countries have come up with procurement reforms e.g. South Africa post 1994. According to Arrowsmith and Trybus (2003) the last decade of the twentieth century has witnessed the start of the global evolution in the public procurement. Nonetheless Thai (2008) asserts that challenges in public procurement go beyond procurement regulations to include procurement process, methods, organizational structure and work force needed for process execution. This assertion is supported by the African Peer Review Mechanism, Country Review (APRM) Report on South Africa 2009, which asserts that non - compliance with the regulations is so high in South Africa. The same report estimated that more than R300 billion is lost every year due to non-compliance. De Boer and Telgen (1998) as cited by Gelderman et al. (2006) explain that compliance is a problem not only in the third world countries but also evident in the countries in the European Union and other developed countries. Gelderman et al. (2006) further advances reasons for non-compliance as explained by the tendency to avoid red tape involved in the procurement process of the public institutions. However Eyaa and Oluka (2011) asserts that the type of goods, services and works procured sometimes influences the degree of compliance with the procurement regulations and prescripts.

\section{Research Literature Review}

\subsection{Comparative Definations of the Private Sector versus Public Sector Procurement 3.1.1. Public Sector Definitions}

Public sector procurement refers to the government activities of purchasing goods, works and services, which it needs in order to carry out its main functions (Arrowsmith, 2010). According to Odhiambo and Kamau (2003) public procurement is broadly defined as the purchasing, hiring or obtaining by any other contractual means, of goods, construction work, and services by the public sector.

According to Migiro and Ambe (2008) public sector procurement offers a reference framework for the composition of public sector supply chains and multilevel networks; actors in public sector supply chain comprise (1) private firms which receive orders from public sector agents, (2) accounting officers and (3) policy-makers.

The case of Zimbabwe: In Zimbabwe, the private sector is governed by the Companies Act, Labour Laws and Product Liability Laws. The public sector procurement is highly regulated by various statues of Parliament where in most instances require a compulsory competitive bidding; which is not always the case with private sector procurement.

\subsubsection{Private Sector Definitions}

According to Leenders and Fearon (2004) supply chain management (SCM) is the systems approach to managing the entire flow of information, materials and services from the raw materials suppliers through factories and warehouses to the end customer. 
According to Christopher (2005) SCM is defined as 'the management of upstream and downstream relationships with suppliers and customers to deliver superior customer value at less cost to the supply chain as a whole'. As per Wisner et al. (2008) also broadly defines SCM as 'the design and management of seamless, value-added processes across organisational boundaries to meet the real needs of the end customer'. The aforementioned definitions portray different views about the way SCM scholars perceives SCM in private sector operations; although SCM definitions might be bit differing to some extent but they can be summed-up into three related categories i.e.: Philosophy of management, Management philosophy implementation and various sets of processes in management (Klemencic, 2006; Lambert, 2006).

According to Handfield et al. (2009) SCM is regarded as a set of three or more organization linked directly by one or more of downstream or upstream flow of services, information and finances from the source to customer (Ghaderi et al., 2010). According to Fawcett et al. (2007) effective management of these flows requires creating synergistic relationships between the supply and distribution partners with the objective of maximizing customer value and providing a profit for each supply chain member.

There is visible difference in terms of the private and public sector procurement objectives, in that private companies are exposed to the harsh and tumbling realities of market competition. The management is assigned with the simple task imposed by their owners to deliver profits today and tomorrow. Since such a goal is easily monitored, one can expect that the approaches developed by successful companies to procure is better suited to minimize costs compared to public procurement managers.

Public sector procurement managers operate under very different and strict conditions in which the threat of bankruptcy is absent, objectives diverse, rigorous evaluation hard to perform, and the prospect of being part of a lawsuit very possible. Drawing on Andersson (2002) one could depict the typical public procurement managers as operating according to a logic defined by hierarchies of legislative environment under which they operate, whereas the private sector procurement manager acts according to market forces. In legislative hierarchies, political influence coexists with the economic incentives of cost-minimization. Two sets of principles are sometimes not compatible. The rights and wrongs are defined within the legislative hierarchy according to its own agenda, which may be partly hidden for outsiders. Market logic is simpler and the private purchaser would have sufficient degrees of freedom to design efficient purchasing arrangements. In private sector procurement profitability is the overriding benchmark against which the performance of the procurement official is evaluated.

\subsection{Research on Public Procurement}

There is comparatively little available theoretical and empirical research in public domain on public procurement. Even very moderate gains in efficiency would result in significant savings for governments. In spite of this, academic research is still in its infancy.

We conclude that the scale-competition problem is acknowledged, but not analysed in depth in the literature. A possible exception is the case of monopsony (Keisler and Buehring, 2005). The focus is on short-run rather than long-run cost savings in most developing economies. The specific issue of how to balance the benefits from economies of scale and supplier competition is scarcely discussed. Other related issues, such as the optimal number of suppliers, have attracted more interest and the conclusions from those studies have some relevance also here (Segal, 1989; Cousins, 2002).

\subsection{Research on Private Procurement}

The available literature on private sector procurement is much greater and of high quality when compared to the one found in public sector procurement. The main thrust of this literature, however, is not on the scale-competition trade-off, but rather on the management of risks, relationships and costs. Recently, the interest has grown, primarily driven by the potential for cost savings. The general impression is that purchasing within private corporations is a more prioritized activity compared to procurement in public institutions. Europe Economics concludes in their 15 country study conducted for the EU Commission that private purchasing is "an integral part of strategy and subject to audit" (Europe Economics, 2006). A good and concise example of these developments is provided by Niezen et al. (2007) who observes that more than half of the cost reductions in successful corporations arise from best supply management activities.

According to Europe Economics (2006) there are three main sources for these savings which are identified. Firstly, leading companies manage to create supplier competition by continually searching for new suppliers and developing alternatives such as 'insourcing'. The potential competitive threat to suppliers ensures cost efficiency. The motion to use sole or multiple sourcing strategies is part of the strategic behavior on the side of the procuring authority, in addition to prices but also include delivery speed, quality, flexibility and non-disruption of supply of goods or services. Secondly, efficient purchasing divisions within successful corporations continually seek to tap knowledge from suppliers and feed it into their own organization. The increased knowledge improves the abilities of corporations to negotiate with new suppliers and to develop alternatives. The third source includes direct initiatives to 'expand the supplier universe' i.e. to stimulate firms to engage in the kind of operations that would make them eligible as suppliers.

\section{Public Sector Procurement Compared to Private Sector Globally}

The private sector is leading when it comes to the flexibility and adoption of new methods of procurement including quick adoption of new procurement technologies. The public sector may be different in this respect partly because it is required to observe special rules and regulations, such as European Union tendering directives in EU and in South Africa, National Treasury Regulations and Practice Notes and in Zimbabwe the procurement is governed by the Procurement Act and Procurement Regulations. These goals for public procurement, set by governments, are often products of compromise and may sometimes be conflicting globally (Erridge, 2005). 
Goods and services must be procured in both private and public sector sectors and in both these sectors the main mandate is to conclude a very attractive and favourable procurement deal for the acquisition of goods and services; however despite these similarities public sector SCM is still different from private sector (Erridge, 1996; Thai, 2001; Thai et al., 2004). The approach to analysing these differences itself differs across various publications and countries. A number of papers consider how the execution of procurement is influenced differently in the public and private sector. According to Covington (2006) there are differences in the attitudes of various stakeholders and role players in private and public sectors. According to Wang and Bunn (2004) the focus on buyer-seller relationships differ through various rules, statues, regulations and procedures that are applicable to public sector only. In the International Trade Center (ITC) public procurement training manual the value derived from public procurement is different from that derived from private sector procurement in terms of responsiveness, professionalism, accountability, competition, transparency. Murray (1999) analyses local government procurement, and lists a number differences with regard to both objectives and more operational issues.

The demands on public sector procurement are far greater than those found in the private sector procurement (Neill and Batchelor, 1999). PIA (the Dutch government procurement organization) estimates that 80 per cent of public procurement is largely similar to that in the private sector (Leyenaar, 2004) consequently approximately 20 per cent of public procurement is different because of different demands (Murray, 1999). What are these different demands that exist in public procurement and are absent in private sector procurement?

Consolidating the existing literature (Leenders et al., 1997; Telgen and Lenselink, 1998; Murray, 1999; Arrowsmith and Trybus, 2003; Burt et al., 2003; Thai et al., 2004; Davis, 2005) and grouping them for clarity and oversight we come to the following listing of additional demands found in public sector:

\subsection{External Demands}

a) Transparency, this is where equal opportunities are afforded to every interested individuals for contracting purposes and all processes leading to an awarding of contracts were made well-known to the public.

b) Integrity in the public sector is expected to be of high standard and for them to do what they promised to do, to avoid improper, irregular, wasteful or corrupt and fraudulent expenditures

c) Accountability refers to the situation where all public organizations and its officials being accountable for the effectiveness, ethical, legal on how the procurement is conducted.

d) Exemplary behaviour, public sector procurement officials are expected to be of good examples in terms of effectiveness and efficiencies in conducting procurement.

\subsection{Internal Demands}

a) Most of public sector organizations have various internal goals like cost efficiency, service delivery etc. on top of these internal goals, the public sector organizations need to meet other external goals by the citizens they are serving like roads, clinics, electricity etc. which might conflict with the internal goals (Callender and Matthews, 2002; Schapper et al., 2006).

b) Public organizations have also political goals to meet, where sometimes community halls are built to keep the youth engaged with musical practice, community meetings etc. but at the same time the same community halls can be used to plot criminal activities (Premchand, 1993).

c) In public procurement there are many stakeholders obviously these many stakeholders (e.g. citizens, taxpayers, electorate, elected officials, management, and procurement officers) may have different objectives (Murray, 1999). But even if they share an objective their interests with that objective may conflict. Some common examples will be a huge demand and need for the sewerage to be treated but none of the citizens would agree for it to be treated in their backyard.

\section{Factors Affecting Supply Chains in the Public Procurement}

First and foremost is a requirement for transparency in public procurement. The public sector procurement transparency refers to the procurement rules, processes; transactions which must be spelled out and be available to the public and also to the potential service providers at large. This requirement affects such areas as advertising of the contract opportunity (i.e. a bid or tender), the public tendering process, the evaluation criteria, process and the awarding of the contract. Moreover, all suppliers must be treated the same regarding access to information, specifications, and the duration of time they have to respond to a bid which later translate to the validity period of a bid i.e. a period between bid closing date and the bid award date in South Africa. In public organization all price, evaluation criteria are publicly known, the opening and closing of bids all are publicly known (National Treasury, 2004).

After the lowest bid has been revealed at the bid opening, the purchasing authority which is the government institution, determines whether the company that submitted that bid is the lowest acceptable bidder and responsive bidder. This may include but is not limited to providing samples or completing integrity questionnaires like SBD/MBD 4 forms, in South Africa this is derived from the National Treasury (National Treasury (2011).

In addition to evaluation tools used in the private sector, such as sample reviews, reference checks, credit checks, site visits, and interviews with principals, many public institutions also conduct background checks on the company, which usually are carried out by investigative agencies such as an NIA or SASS or SIU and others in South Africa. These investigations may also include the owners and principal executives of the bidding companies; these investigations are also backed up in South Africa by the National Treasury List of Tender Defaulters and List of Restricted Suppliers (National Treasury, 2008).

Public procurement is also subjected to various jurisdiction influences which also further add complexity in the public procurement operations. For example, the inclusion of the South African National Housing Policy, CIDB, NHBRC etc. therefore procurement is influenced by and subject to the jurisdiction of these separate government organizations. Public procurement professionals can utilize "preferred suppliers" that have a special status bestowed 
by a particular national, provincial and local sphere of government. Under the preferred supplier system, then, the purchasing authority may end up paying a higher price. But that may be partially offset because "preferred" status exempts suppliers from background investigations and liquidity checks (National Treasury, 2004).

The "backdrop" contract is another tool that is commonly used by public sector procurement professionals. "Backdrop" refers to contracts that have been pre-negotiated by another government organization for example in South Africa, by the National Treasury or by the Provincial Treasury through the Transversal Contracts Unit. Because they eliminate many of the investigative steps mentioned earlier, public sector procurement professionals often use this type of contract to speed up the procurement process although on the local sphere of South Africa government procurement managers are still not fully aware of the process to engage this type of contracting for procurement. Contracts concluded through Backdroping saves lot of money and time, however it is not always easy. While price-competitive is good, the lowest price is not assured and the possibility of further negotiation may be contractually limited (National Treasury, 2004).

A special type of backdrop contract is the "piggyback" contract. These are agreements between a government institution and a supplier that can be replicated by another government institution with the supplier's permission. Like backdrop contracts, piggyback contracts are generally not subject to background checks and therefore the contracting and procurement process can take considerably less time than traditional procurement contracts. Normally these types of contracts in South Africa are referred to as 'Contracts arranged by another organ of State'. According to the National Treasury (2005) Regulation 16A6.6, "The accounting officer or accounting authority may, on behalf the department, constitutional institution or public entity, participate in any contract arranged by means of a competitive bidding process by any other organ of state, subject to the written approval of such organ of state and the relevant contractors."

According to the National Treasury (2012) for Public Financial Management, this provides a national perspective to address financial management capacity constraints in the public sector including the procurement. Skills of the procurement professionals often are different in public and private sector supply chains. A recent study by McKinsey \& Company and the Institute for Supply Management (ISM) showed that public sector procurement professionals "lag behind private sector companies on several performance dimensions, including efficiency of purchasing tools and processes, capabilities, and performance management." One reason for this disparity is that mastering supply chain management requires ongoing study. It is only in the last decade or so that private sector best practices have been introduced to public sector procurement managers.

However, because public organizations are under increasing pressure to reduce costs, more public sector procurement managers are now seeking outside training and knowledge that will help them to improve their operations like employing more of the consultants which the Auditor-General of South Africa raised it as concerning practice which must be stopped as various government institutions are now not doing their mandatory duties because they rely too much on consultants (Nombembe, 2013). "Procurement isn't just a job: good procurement is a skill and it needs to be recognized as such" (Oughton, 2007). There is probably no other way to obtain such skills else than learning through experience.

\section{Partnership between Private and Public Sector in Procurement}

\section{Public \& Private Sector}

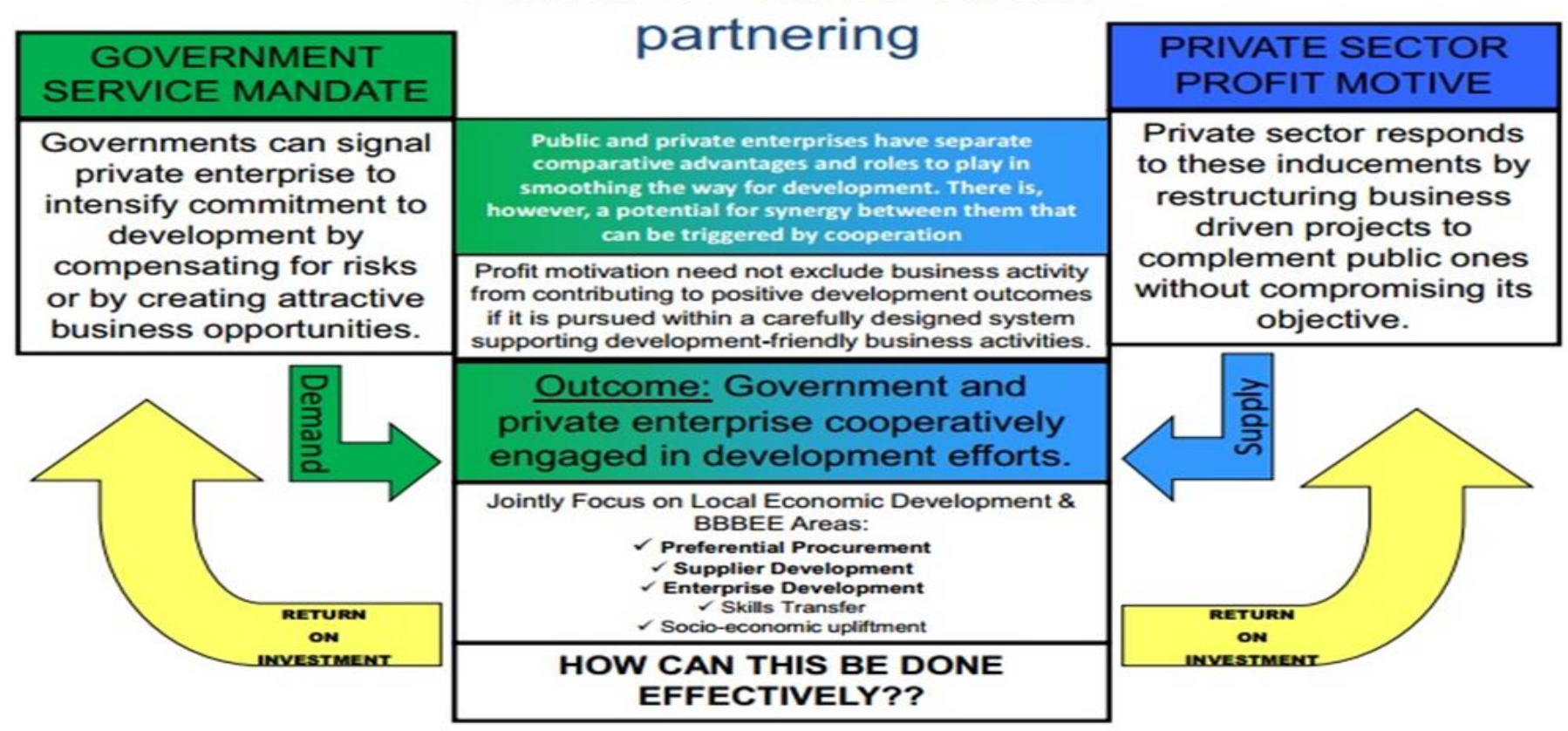

Fig-1. Partnership between Private and Public Sector in Procurement

Source: South African Supplier Diversity Council (2013)

According to SASDC (2013) the above Figure 1 illustrates that partnership can be fostered in order to give competitive advantage to both public sector and private sector procurement operations; this can be achieved by examining some similarities between the two procurement sectors.

Public sector procurement usually deals with service delivery to the citizens and private sector organizations. These services typically involve direct contact with people for example, hospitals, police, education or justice and cannot be as easy as the production of goods rationalized by replacing humans with machines. Most goods and services are produced by the private sector. Their production pattern is becoming more similar to that of the public 
sector, for example, initially there were no private security companies but in nowadays it is a booming business. In nowadays most services which were predominately government offered are now wholly or partially offered by the private sector. In this sense, the distinction between the private and the public sector is becoming more blurred; when it comes to specific services like hospitals, security etc. citizens prefer private hospital and security rather than the public services (SASDC, 2013).

Table-1. Summary of similarities and differences of the public sector and private sector procurement

\begin{tabular}{l|l|l|l}
\hline \multicolumn{3}{l}{ Table-1. Summary of similarities and differences of the public sector and private sector procurement } \\
\hline Competition & Private & & Public \\
\hline Size of organizations & yes & no & \\
\hline Geographical dispersion & $1-10.000+$ & $1-10.000+$ & \\
\hline$-\quad$ Local & & & \\
\hline$-\quad$ Regional & yes & yes & \\
\hline$-\quad$ National & yes & yes & \\
\hline$-\quad$ International & yes & yes & \\
\hline Production & yes & Yes (few) & \\
\hline$-\quad$ Goods & & & \\
\hline$-\quad$ Services & yes & no & \\
\hline Profit driven & yes & yes & \\
\hline Openness & yes & no & \\
\hline Contacts with customers & no (limited) & yes & \\
\hline Source: SASDC (2013) & vary & many &
\end{tabular}

According to the Table 1 above further emphasis is detailed on differences and similarities of both two sectors to enhance partnership between public and private sector procurement. Despite the aforementioned differences between public and private sector procurement, there are still important similarities i.e.:

- Both sectors share a common goal, which is to obtain the best value for the organization. This means getting the most from each rand spent at every step in the supply chain. In the public sector spending efficiency equals organizational efficiency; this applies not just to purchasing but to the entire supply chain value operations.

- Customers or service consumers i.e. public citizens continue to demand better quality, faster service, and lower cost. If an organization cannot continuously and consistently provide materials "better, faster, and cheaper," then its long-term survival is doubtful.

- In real terms more and more pressure is exerted to both private sector and public sector procurement in that services, materials, information etc are expected to be of high quality despite the high scarce and shortages in resources for both sectors. The reality is also evident in that the government is now and again considering reducing its staff compliment as it adds high costs to the wage bill; therefore the government considers to outsource most of its services.

Furthermore Oughton (2007) avers that another way that public and private sector procurement are similar is that they are both subject to three trends that are driving change, which are:

- The public sector and private sector procurements need the total process visibility in order to speed the sourcing of goods and services and decrease the inventory costs and improve the cash liquidity. The reality for public sector supply chain managers is that they, too, need to eliminate costs from the supply chain to ensure their organizations' long-term sustainability.

- The private and public sector procurements must become more responsive. In a world where continuous improvements in information, communication and technology lead to shorter shelf lives for many products, supply chains have an increasingly difficult job of maintaining a relevant portfolio of materials and services while avoiding the losses caused by holding obsolete material. Material liquidation is a multibillion-dollar industry that exists because of supply chain inefficiency globally. Responsiveness keeps obsolescence to a minimum standard.

- The private and public sector procurements must have transparency, where transparency is not only about compliance to forms, rules, and regulations. It also encompasses the ethics in dealing with relationships in business operations. Transparency is highly possible for both public sector and private sector procurement to have procurement operations that are based on trust and sharing of information which will lead to innovations and improved service delivery.

In most cases the public sector procurement is not that much different from that of the private sector, because public sector customers demand that service delivery must happen very fast and cost effectively. It can be done by using private sector principles such as strategic sourcing, supplier relationship management, and inventory control in a way that is acceptable in public sector settings.

\section{- Public and private sector procurement are two sides of the same coin}

In the final analysis, Oughton (2007) alluded to the fact that it is how well these concepts work that truly determine their worth; it is clear that public and private sector supply chains truly are "two sides of the same coin" and that many private sector best practices can be used in the public sector with great success and with little or no modification; thereby fostering the much needed partnership between these two sectors. By focusing on three areas strategic sourcing, supplier relationship management, and inventory management, public sector supply chains can make order of magnitude improvements, generate real savings, and create even more supply chain successes. 


\section{Challenges from the Political Ambiance}

Various public supply chain managers in the procurement of goods, services and works are confronted with many challenges, especially from the political environment. The distinction between the administrative and political environment (i.e. political oversight role) has become increasingly fuzzy, because the political environment is interfering more and more in the administrative environment (Mafunisa, 2006).

Public sector supply chain management is different from private sector supply chain management primarily because of the constraints imposed by the political environment within which the management processes are conducted. An important difference is that the ethical values and norms applicable to public organisations vary considerably from those private organisations. Political authority and public accountability are two ethical norms specifically for public institutions. Public institutions are subject to a very large range of legislative restrictions, controlled by the legislative, executive and judicial authorities and subject to criticism by the public at large (Fourie, 2009).

As per the Republic of South Africa Constitution, Act No. 108 of 1996, civil servants' duty is to 'succumb' to their political heads; they carry out ministerial instructions and ministers are answerable to the public, that is, to Parliament, for the management decisions that are made in their name. Some of the difficulties that have arisen, involving public criticism of named public servants, are the result of ministers' failing to act in accordance with accepted constitutional practices. Not only have ministers not accepted full responsibility for decisions made in their name, but ministers can intentionally mislead or misinform Parliament and its committees which is unethical in terms of the current Rules of the National Assembly (Parliament). In such circumstances, public procurement managers have to decide where their duty and loyalty lies: to Parliament (that is, the public) or to their ministers. They have to make an ethical personal judgement about how they should behave or take decisions. Apart from the questions of accountability and transparency, there is also the ethical issue of discretionary decision-making. Officials throughout the public service make management decisions involving discretionary judgements on individual issues or where cases of the national interest have to be adjudicated against private actions on a daily basis. Those making such judgements are expected to apply the highest possible ethical standards (Fourie, 2009).

The involvement of officials in management decision-making raises various ethical questions. It requires, inter alia, good people management skills and especially the ability to listen to lower levels of employees, which is a big challenge in the public service because ranks are so important and managers make use of them to disregard lower ranking employee's views or opinions. It also requires good communication and negotiating skills, since the opinions of employees have to be reconciled with those of management (Fourie, 2009).

\section{Lessons to be learned by Public Sector from Private Sector Procurement Practices}

According to Lundvall et al. (2008) some of the lessons to be learned by the public sector from the private sector procurement are as follows:

\subsection{Communiqué}

Communication between buyers and suppliers is seldom satisfactory. As a consequence, suppliers have often experienced that public procurement managers ask for products or services that are not first-best to satisfy actual needs or do not reflect the current level of technology in the market. This can be seen as a failure in communication between the parties which need to be addressed in a proper way. Better communication enables suppliers to better understand what products are the most appropriate to satisfy the needs as effectively and efficiently as possible.

Little communication between public procurement managers and suppliers bluntly reveal that public officials seldom spoke to suppliers. At the stage in which the tender requirements were specified, some contacts may occur, but far from always and virtually never after this phase. As a consequence, it becomes very hard for private corporations to fully understand what the tender exactly is about and what needs that are to be fulfilled. If tenders were more flexible, this would probably not constitute a significant problem. However, given that tender specifications typically are highly detailed, new and innovative solutions may be defined which results in frustration among innovative firms engaged in developing new technologies (Lundvall et al., 2008).

\subsection{Flexibility}

The flexibility for suppliers to propose alternative products is often unduly restricted in tender specifications for public sector procurement. Public procurement managers often put an improper weight on conditional requirements in relation to flexible award criteria. Others stress the importance of conditional requirements but agree that public procurement managers are too restrictive in setting the general Terms of Reference for the tender. This hampers innovation, limits the quest for cost-efficient solutions and complicates procurement processes as well as worsens conditions for SME. Private companies are generally better at allowing suppliers sufficient maneuvering space for innovation and new solutions. Tender specifications often too narrow, many tenders involve too many conditional demands in relation to awarding criteria therefore public procurement managers need to loosen their grip a bit. Observation is that conditional demands in the private procurement managers often are negotiable. In other words, if a prospective supplier had good reasons, there is always a possibility to contact the private procurement managers and argue for a change.

A general concern among SMEs is a low level of trust of the fairness of the procurement process and that the best offer ultimately is selected. The single minded price focus contributes to these worries. According to Lundvall et al. (2008) there is a contrast, in that the private sector often considers performance equally or even more important than price. Private procurement managers are said to be more interested in the performance than costs. The strong price focus may result in firms, in particular SME, abstaining from bidding. There is also a fear of being subjected to some sort of litigation should a bid be successful but legally challenged by a larger competitor. Another lack of flexibility is the common strict demands of relevant and extensive references. References for newly established 
SMEs and companies may be very low or non-existent. Over relying on firm referencing makes entry harder for new firms and for SMEs which may limit competition.

\subsection{Certainty}

Predictability regarding what future tenders will require is generally considered as poor in public sector procurement. In some industries and for some activities, firms may need to invest in research and development $(\mathrm{R} \& \mathrm{D})$ long before the actual tendering procedure is started in order to meet these demands. If firms are uncertain on tomorrow's demands in public procurement, they may find it too risky to invest. Better predictability can stimulate innovation in the right direction. This argument has been stressed by many scholars in particular to environmental friendly procurement performance. Improved predictability is also warranted on when tenders can be expected to be announced which would enable firms to be better prepared. Sufficient time between the tender phases (announcement, validity period, awarding and start of delivery) is often a prerequisite for the participation of SMEs in public procurement.

It is difficult to correctly foresee future conditional demands on public procurements. Sometimes, demands come as a surprise when the tender is published and it can be hard for some enterprises to meet them within the postulated time limits. Had the procurement officials declared such goals well in advance, it is likely that more companies would have had time and resources to meet them; therefore private sector is better equipped in pursuing such objectives.

\subsection{Knowledge}

It is paramount to carefully evaluate procurements through the entire life cycle and feedback the lessons learnt into future procurements to have a Body of Knowledge (BoK) readily available. This aspect has a strong dynamic implication, private companies are generally felt to be far better than public at evaluating supplier contracting processes and learning. Also, thorough monitoring during the contract life may provide strong incentives for the supplier to maximize performance in the delivery phase.

Incentives to perform in private versus public sectors are totally different; hence learning plays a central role. In private sector procurement the buyer constantly monitors and registers the performance of the suppliers in order to maintain pressure for optimal performance. The supplier knows that dissatisfaction of performance may result in an immediate disruption of order from the client or termination of the contract. Long-term relationships are the norm in the private sector procurement. In public sector procurement, as long as delivery is acceptable according to tender specification, the supplier is paid the agreed amount. Performance in excess of what is promised is as a general principle not rewarded. In other words, irrespective if a supplier only barely fulfills the public procurement contract or fulfills it with outstanding excellence, the termination date and compensation scheme remains unaffected. Hence, during the delivery phase there is virtually no incentive for suppliers to improve performance in excess of the minimum as stipulated in the contract.

In the private sector procurement, the picture is often the opposite. There are often strong incentives for high performance put in place during the life of the delivery phase. These incentives concern both monetary rewards as well as an increase probability of contract extensions in time or volume. Performance monitoring and learning in the government sector is an area that is regarded as underdeveloped, including national, provincial and local government institutions.

\section{Research for the Future}

The literature review undertaken on the topic and others, has shown that electronic supply chain management (eSCM) or e-procurement, under e-commerce, has been acknowledged as an outstanding topic in the supply chain management especially in the public sector procurement literature, in the most prestigious Operations Management and Logistics journals, especially since year 2000s. The main topics have been e-procurement, e-fulfilment and information flows for private sector procurement mainly.

Further research regarding the e-SCM process, should try to analyse how different business units can use the same customer data for the betterment of public sector procurement ultimately the service delivery. Moreover, it should try to determine what specific type of integration alternatives are available, for organizations working with rapidly changing customer relationship management (CRM) systems and SCM support technologies. Future studies should also develop decisions and identify tools used to analyse the large amount of data, gathered through the internet for SCM purposes.

E-procurement is a tool; it will not change anything in procurement operations either in private or public sector strategically. E-procurement cannot replace professional buyers, their knowledge of the needs of users and organizations, their experience in judgment of what is mandatory and what is optional, usage of evaluation models to weight different requirements against each other and their negotiating skills. Suppliers will still inform presumptive buyers, including public administration buyers about their new products, possible solutions and technical development and also collect information development trends and needs of the public administration.

Finally, more empirical studies, showing how the internet is used to provide different product and service offerings, are required. It would be preferred that such research be conducted on bigger sized departments and developing countries, as these will enhance the scope of coverage, producing more statistical data, thereby assisting the Public Sector administration as a whole, especially on SCM and procurement.

\section{Conclusion}

In conclusion, it would be prudent to note some of the differences compounded with some similarities between the public sector and private sector procurement processes. In trying to foster the much needed partnerships between these sectors, one can conclude that the public sector has got more important lessons to learn from the private sector 
procurement processes in order to transform the public sector procurement into better, effective and efficient procurement; referring to the flexibility, proper and timeous communication with suppliers, allowing for innovations from suppliers, doing all this without compromising integrity and transparency which are the pillars of most public procurement institutions.

Owing to the fact that there is less thorough research done in the field of public sector procurement, one can further conclude in saying that the focus is on short-run rather than long-run cost savings in most developing economies public sector procurement. The specific issue of how to balance the benefits from economies of scale and supplier competition is scarcely discussed as opposed to the private sector.

\section{References}

Andersson, F., 2002. Konkurrens på kommunala villkor. En översikt., Ájour Nr 7, Svenska Kommunförbundet.

Arrowsmith, S., 2010. Public procurement: Basic concepts and the coverage of procurement rules. In S Arrowsmith (Ed.), Public procurement relations: An introduction. Nottingham, UK: EU Asia InterUniversity Network. pp: 1-31.

Arrowsmith, S. and M. Trybus, 2003. Public procurement: The continuing revolution. Kluwer Law International.

Burt, D.N., D.W. Dobler and S.L. Starling, 2003. World class supply management: The key to supply chain management. 7th Edn., New York: Irwin/McGraw-Hill.

Callender, G. and D. Matthews, 2002. The economic context of government procurement: New challeges and new opportunities. Journal of Public Procurement, 2(2): 216-236.

Christopher, M., 2005. Logistics and supply chain management: Creating value-adding networks. 3rd Edn.: FT Prentice Hall.

Cousins, P.D., 2002. A conceptual tool for managing long-term inter-organisational relationships. European Journal of Purchasing \& Supply Management, 8(2): 71-28.

Covington, C., 2006. Return on investment vs. Return for human. Source NIGP, 2: 3-4

Davis, P., 2005. Supply strategies for the public sector. Proceedings of the 14th Annual IPSERA Conference, Archamps, France, 20-23 March. pp: 519-520.

De Boer, B. and J. Telgen, 1998. Inkoopmanagement in de zorgsector. Deventer, the Netherlands: Kluwer Bedrijfsinformatie.

Erridge, A., 1996. Innovations in public sector and regulated procurement. In: A. Cox (Ed.) Innovations in procurement management. UK: Earlsgate Press.

Erridge, A., 2005. UK public procurement policy and the delivery of public value. In K. V. Thai et al. (Eds), Challenges in public procurement: An international perspective. Boca Raton, FL: PrAcademics Press. pp: 335-352.

Europe Economics, 2006. Evaluation of public procurement directives. Markt/2004/10/D, Final Report.

Eyaa, S. and P.N. Oluka, 2011. Explaining non- compliance in public procurement in Uganda. International Journal of Business and Social Science, 2(11): 35-44.

Fawcett, S.E., L.M. Ellram and J.A. Ogden, 2007. Supply chain management: From vision to implementation. Upper Saddle River, New Jersey: Prentice Hall.

Fourie, D.J., 2009. Ethical conduct as the cornerstone of public sector procurement.

Gelderman, P.W. Ghijsen and M.J. Brugman, 2006. Public procurement and eu tendering directives - explaining non-compliance. International Journal of Public Sector Management, 19(7): 702-714.

Ghaderi, H., S.A. Darestani, Z. Leman and M.Y. Ismail, 2010. Development of soft network model to improve supply chain management performance of SMEs. Sci. Res. Essays, 5(13): 1759-1764.

Handfield, R.B., R.M. Monczka, L.C. Giuinipero and J.L. Patterson, 2009. Sourcing and supply chain management. 4th Edn., Ontario: Southern Western.

Keisler, J. and W. Buehring, 2005. How many vendors does it take to screw down a price? A primer on competition. Journal of Public Procurement, 5(3): 291-317.

Klemencic, E., 2006. Management of supply chain: Case of Danfoss District heating business area. MA Thesis, Faculty of Economics, Ljubljana University, Slovenia.

Lambert, D.L., 2006. Supply chain management: Processes, partnerships, performance. 2nd Edn., USA: The Hartley Press.

Leenders, M.R. and H.E. Fearon, 2004. Purchasing and supply chain management. 11th Edn., Chicago: Irwin.

Leenders, M.R., H.E. Fearon, A.E. Flynn and P.F. Johnson, 1997. Purchasing and supply management. 12th Edn.: McGraw-Hill Irwin.

Leyenaar, P., 2004. Overheidsinkoop: Een klasse apart. In: Inkoop voorbij 2004, een spiegel voor de toekomst. Netherlands: NEVI, Zoetermeer. pp: 141-152.

Lundvall, K., J. Tops and H.B. Olesen, 2008. What can public procurers learn from private? , Denmark: Konkurrensverket.

Mafunisa, M.J., 2006. The role of public administration in promoting ethical conduct in elected officials: Overview of post 1994 South Africa. Journal of Public Administration, 41(3): 506-519.

Migiro, S.O. and I.M. Ambe, 2008. Evaluation of the implementation of public sector supply chain management and challenges: A case study of the central district municipality, North West Province, South Africa. African Journal of Business Management 2(12): 230-242.

Murray, J.G., 1999. Local government demands more from purchasing. European Journal of Purchasing and Supply Management, 5(1): 33-42.

National Treasury, 2004. Supply chain management a guide for accounting officers/authorities. Republic of South Africa, October.

National Treasury, 2005. National treasury regulations. Republic of South Africa, March.

National Treasury, 2008. National treasury circular checking the prohibition status of recommended bidders prior to awarding any contract. Republic of South Africa. February.

National Treasury, 2011. National treasury instruction note on enhancing compliance monitoring and improving transparency and accountability in supply chain management. Republic of South Africa, May.

National Treasury, 2012. National treasury capacity development strategy for public financial management. Republic of South Africa, January.

Neill, P. and B. Batchelor, 1999. Bidding for recognition. Supply Management, 2.

Niezen, C., W. Weller and H. Deringer, 2007. Strategic supply management. MIT Sloan Management Review, $48(2): 7$.

Nombembe, T.M., 2013. Report of the auditor-general. Republic of South Africa.

Ntayi, J.M., R. Gerrit and S. Eyaa, 2009. Supply chain swiftness in a developing country: The case of Uganda small and medium sized enterprises. E-Journal of Business and Economic Issues, 4(1): 2011-2014.

Odhiambo, W. and P. Kamau, 2003. Public procurement: Lessons from Kenya, Tanzania and Uganda. (Working Paper No. 208). Paris, France: OECD Development Centre.

Oughton, J., 2007. Efficiency in government procurement. Rusi Defence Systems.

Premchand, A., 1993. Public expenditure management. Washington, DC: International Monetary Fund.

Schapper, P.R., J.N. VeigaMalta and D.L. Gilbert, 2006. An analytical framework for the management and reform of public procurement. Journal of Public Procurement, 6(1-2): 1.

Segal, M.N., 1989. Implications of single vs. Multiple buying sources. Industrial Marketing Management, 18(3): 163-178.

South African Supplier Diversity Council, 2013. Public and private sector procurement from SMME's as a stimulant for economic growth. SASDC Conference: Johannesburg.

Telgen, J. and M. Lenselink, 1998. Inkoopmanagement in de zorgsector. Deventer, the Netherlands: Kluwer Bedrijfsinformatie.

Thai, K.V., 2001. Public procurement re-examined. Journal of Public Procurement, 1(1): 9.

Thai, K.V., 2008. Measuring losses to public procurement corruption: The Uganda Case. 3rd International Public Procurement Conference Proceedings, (August 28-30). 
Thai, K.V., C.M. Harland, G. Callender, L.A. Knight, J. Telgen and H.L. Walker, 2004. Public procurement as a lever of government reform: International research evidence. Proceedings of World Wide Symposium, San Diego, California, 6-8 April. pp: 58-68.

Wang, S. and M.D. Bunn, 2004. Government/business relationships: Insights into contract implementation. Journal of Public Procurement, 4(1): 84.

Wisner, J.D., K.C. Tan and G.K. Leong, 2008. Principles of supply chain management: A balanced approach. Mason, Ohio: South Western Cengage Learning.

World Bank, 2005. Country Procurement Assessment Report, Report No. 25334-LA. Washington, DC: Author. pp: 21. 